\title{
Islamization of Accounting Policies as a Solution to the Ethical Problem in Accounting through Accounting Education
}

\author{
Saikou Gassama ${ }^{1}$, Tjiptohadi Sawarjuwono ${ }^{2}$ Hamidah $^{3}$ \\ ${ }_{1,2,3}$ Department of Accounting, Faculty of Economics and Business, Universitas Airlangga, Indonesia \\ Saikoogassama@yahoo.com
}

\section{Abstract}

There is a growing concern for accountant involvement in the continuous scandals which is due to the ethical judgments of certain accountants and amount of academics recommend that the school system is partly responsible. The ethical elements of accounting education were found to be inadequate, so there is a lack of meaningful attention to tackling accounting problems. In the first place, the purpose of this study is to highlight the importance of ethics in accounting education. Second, the paper argues that in the application of accounting ethics, specifically Islam, accounting education should concentrate on religious codes of ethics and values. Furthermore, this research explored the ethical viewpoint of Islam and how it gives some insights into the process of creating a more harmonized and ethical accountant. This study suggests the Islamization of the ethical concept of accounting as a solution to the ethical challenges the accounting profession is confronted with, in the form of the introduction of Islamic ethics in accounting curricula to be taught as part of the ethical accounting education method., the paper is a concept paper using other publications on the topic with the aimed of suggesting good system of accounting education that will produce accountants with excellent ethics.
Keywords

Islamization; accountant; ethics education solution

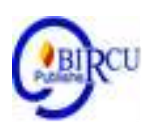

\section{Introduction}

Accountants provide the duty to an organization to provide clear details for choicemaking. There is an increased concern that, on a number of jobs, accountants will not provide the information required by users, given the presence of professional ethics guidelines established by the institute of chartered accountants, certain accountants still behave unethical (IMA) (Jaijairam, 2017). There is also raising concern about the lowest recorded unethical standards of certain accountants. There is still rising academics indicating that some of the faults should be borne by the education system. They raised questions about the need to look at the kind of training method that creates experts in Accounting that, intentionally or otherwise, tend to be behaving ethically immoral, is a collection of beliefs or moral standards (Yarahmadi and Bohloli, 2015). Realizing the lack of ethical components in accounting education (Graham et al., 2013). This study attempts to discuss the ethical issue of the accountancy profession and the school system. The study means that the sample to ethical issues lies in the application of religious ethical growth and principles rather than simply concentrating on the secular essence of ethics and the ethical code of conduct of accounting ethics. The study proposed that a solution to the 
problem of creating a more ethical and socially responsible accountant could be offered by the Islamic perspective and ethical viewpoint. This study also describes Sharia's Islamic legal standards as an ethical structure to be seen as a way of resolving ethical conflicts that accountants usually face.

The aim of the study is to resolve the courageous unethical and cultural unprofessional conduct of certain accountants by integrating Islamic teachings and culture. Islam provides theological basis for number of some personal qualities which facilitate economic growth (Salahudin, Baharuddin, Abdullah, \& Osman, 2016), They have a huge influence on the lives of many people. Here, we also tried to inspire accountants to participate and strive to understand and apply Islam and the development of Islamic law or Sharia law to represent the diverse concepts of jurisprudence in order to have access, in terms of accounting, to the practical growth of Islam (Kamla, Gallhofer, \& Haslam, 2006). Accountants are often known to be the regulators of financial system. Through accountants ensuring the consistency and honesty of financial information, stock markets would be much inefficient, capital costs would've been higher, and the quality of life would be lower (Beattie, 2000). As discussed in the beginning section, this study addresses the need for accounting profession to include ethics as part of a comprehensive curriculum in which accountants, from an Islamic point of view, it is important to liberate themselves from a secular mindset that considers ethics as another form of technical and worldly thought existence. This study indicates that the Islamic education of accountants should be inculcated in the accounting curriculum from school level to university, because relationship between schools and the community is a mutual relationship. Schools are a means to foster and develop students' abilities in school. Schools are trusted by the community to educate, train, foster and develop the abilities of their children education ( $\mathrm{P}$ \& Andriyani, 2020). In order to receive God's ultimate blessing on earth, Islam really considers the job of accountants to be important in establishing the proper management of this universe, ethics regulates all facets of life, in Islam. As the Prophet (Peace be upon him) said, "I was sent only to perfect the ethical system." (Mahdavikhou \& Khotanlou, 2012). The study argues in this section that, In order for accountants to be able to really function, in a business society as moral judges, they must therefore be well ethically trained and Islamic ethical structure could be best for accountant. That's where the paper introduces the Islamic legal principles as the basis for formulating the requisite objectives for the accountants to conduct the work. Accounting education in this regard must be defined by instilling in the ethical decision-making process the necessary phases, including moral values and the national interest.

The implementation of Islamic ethics in Accounting as a tool for teaching accounting ethics education is suggested in this research. In the final semester, the final year undergraduates will take the curriculum to incorporate and put in correctly and properly context the understanding of accounting methods and professional concepts they have learned in previous studies. First, the importance of Islamic philosophy, in this worldly life, and beyond, such as Islamic faith, the role of men, and in executing their duties. It is important to introduce Islamic philosophy and ethics to students and then, later on, to relate all these concepts to issues of ethics and the ethical issues in accounting. The Code of Professional Conduct of the AAOIFI (Accounting and Auditing Organizations of Islamic Financial Institutions) can be used as a material to explain and educate students about the characteristics of ethical awareness and principles from an Islamic perspective. The purpose of this study is to implement a new approach to ethics education in the accounting industry by incorporating Islamic ethics into all accounting education courses. (Mahdavikhou \& Khotanlou, 2012). 
Ethics curriculum need to mainly focus on at least three (3) main topics. Ethics should not, first of all, be seen as another subject that will be determined by students. Islamic ethics is nothing like that and should be taught as a topic in which students should respond to the great ethical dilemmas they have experienced in the accounting curriculum as well as the possible moral issues they may face when entering the accounting profession. Second, the non-critical incorporation of professional standards of conduct is not mandated by ethical training. Critical conversations and debates on the Code of Professional Conduct should be presented to students and ethical standards should not be treated as merely informative notes. For students to better understand ethical principles, there needs to be a consistent educational structure and digital or e-learning needs to be built to improve learning flexibility and make the materials usable and easily accessible (Khafit, Sulastri, \& Fauzan, 2020). Learning the philosophy is otherwise not so important at the end of the day, though understanding general ethical principles and concepts can be beneficial. The study argues that ethical training should strive to humanize accounting students, that is, to give rise to a sense of moral responsibility towards people. As rightly pointed by Mahdavikhou and Khotanlou (2012) Islamic ethics should be incorporated in education in accounting and, in particular, emotional loyalty to other individuals should be promoted. Thirdly, it is also suggested that an improvement in ethical allegiance to other persons may have to go some way to countering the attempts of accountants to rob others.

A systematic code of ethics covering the handling of financial transactions of both profit and non-profit entities has been formulated by Islam as well. This is also reinforced by (Basri, Siti Nabiha, \& Majid, 2016) Islam is not only about a series of religious rites and rituals; it is a complete and holistic package designed to shape human life and to uplift the human spirit at the same time. The definition of accounting in Islam is derived from the Qur'an, which makes some samples to the principles of accounting.(Kamla, 2015). According to the Islamic economic system, the core of the economic problem is not lack of production, but rather the problem of distribution (Martinelli et al, 2019). Muslims are required to record their transactions, and the coming of Islam and the revelation of the Quran have offered such an emphasis on recording guidance on every aspect of life, including economic transactions. In fact, the roots of the Islamic economic structure are drawn from the Qur'an itself, providing instructions on how to conduct business in an appropriate way. Therefore, it was both necessary and unavoidable to establish an Islamic system of accounting. In fact, the Qur'an also included guidance on how to conduct accounting activities and seeing that as the divine revelation began around $610 \mathrm{CE}$, this would mean that Islamic accounting was present some 800 years before the book of Pacioli. (Trokic, 2015).

Like other religions, Islam has its own world-view and belief structure, but it is not limited to individual realms. Islam is a cohesive political, economic, cultural, and religious framework for human life and all other important and powerful aspects. Therefore, the distinction of science and religious guidance for Muslims is not admissible. The accounting method, which itself is part of human intelligence, is believed by many Muslim scholars, and this is what Islamic accounting is called (Rezaei, n.d.).

Accounting systems that identify, measure, record and evaluate the entity's financial aspects on the basis of an accounting procedure that provides appropriate information to the stakeholders of the entity (not only limited to financial data) Consequently, it will allow them to ensure that the agency functions consistently in the evaluation of its socioeconomic goals, in order to determine their own accountability to Allah (Arif Billah \& Islam, 2015). and accounting in formation need to be forward looking information, forward looking information reveals the things that will be done by the company in the coming year 
as well as information regarding projections on the results of the analysis of the company's condition in the future (Rahmani, Maksum, Fachrudin, \& Silalahi, 2020). Since Islam has its own cohesive rules governing how to run a company, if genuine Muslim customers are to be of any importance, the implementation of Islamic accounting theory and practice must be followed.

Therefore, because In societies that have exposed doctrines and morals that control all social, economic and political facets of life, such as the case in Islamic societies, the conceptual structure of Western-based accounting systems has been developed to understand the dichotomy between business morality and private morality (Arif Billah \& Islam, 2015). For accounting educators and researchers, input from industries regarding the efficiency of accounting education is very significant. This kind of input makes it possible to incorporate the problems that the organization wants in the curriculum (Kutluk, Donmez, Utku, \& Erdogan, 2012). Since this issues are admitted by the conventional accounting system there is need to enrich our accounting curriculum with Islamic ethics. And in a study by (Costa, Torrecchia, \& Sangster, 2013) states that in Italy is accounting that has always played the main role in business industry so changing the education and the training of teachers will have huge impact. In the sense of Islam, the main objective of Islamic business is to obtain the pleasure of God by obeying the Quran and Sunnah. In line with this idea, the main objective of Islamic business is to obtain the pleasure of God by obeying the Quran and Sunnah (Indrawaty \& Wardayati, 2016). In Islam, accounting should not only serve as a service that provides financial information to users and the general public, but, more importantly, accountants should fulfill their responsibility by providing information by showing the society as obey God's commandments in their services (Rahim \& Rahman, 2003b).

There are strong institutions that make Islamic ethics implemented very easily, such as AAOIFI which has an establish structure consists of the executive committee, with a defined structure. While the professional board of Sharia forms the organization's working standard obligations, accounting and auditing, governance, and ethics. In addition, through conferences and training, standards and journal publications, membership and professional exam-based certifications, and to participates in standards-related activities such as promotional events (Hassan, Aliyu, Huda, \& Rashid, 2019). The position of accountants has been found to rely on the ethics of the accounting profession. (Enofe, Nakpodia, \& Moruku, 2014). Significant steps in ethical accounting education have been taken, but after the well-known recent accounting scandals, it seems absolutely important to pay increasing attention to accounting ethics and improve ethical education for accountants (Melé, 2005). Professionalism in accounting, ethical investing and corporate reporting. The study by Melé, Rosanas, and Fontrodona (2017), Suggesting more study to better incorporate the technical dimensions of accounting and finance into the business of human operation and to better understand ethics not just as a law, but as a mutual and interdependent set of values, virtues and principles (human goods).

With the fall of the Islamic state, Islamic economics also diminished and played second fiddle to the traditional system that dominated world economics. The colonization of Muslim dominated nations by Western empires has had powerful effects on culture and every aspect of social life. This included principles of accounting that were introduced in those nations. They still had considerable western influence, including those majority Muslim populated nations that were not colonized, (Trokic, 2015). In the new information age and the business world, the accounting profession needs to preserve transparency and provide accurate financial statements. Accountants that are responsible for producing accurate, concise and timely financial reports must also meet the highest standards for 
professional responsibility. However, ethical behavior among accounting experts is not always guaranteed (Góralska, 2016). Many Muslim scholars claim that the accounting system, which is part of human understanding itself, should be related to Islamic religious teachings, and this is what is called Islamic accounting (Rezaei, n.d.).

A significant feature of the Islamic accounting system is the fact that it is based on the concept of ownership. This is because, in the light of Islam as a canon of principles, everyone is accountable for their own acts as well as the economic and financial activities they are responsible for. (Czerny, 2018). One of the fundamental differences between the Western and Islamic economies, reflected in the formation of the accounting system, is the approach to tax problems. In Western countries, the tax is seen as a burden that corporations should, if possible, avoid (which results from the focus on profit and assessment of the effectiveness of business operations from this perspective). For a Muslim, zakat "alms" (the literal sense of the word) is a way of adoring and fulfilling the commandment of Allah, which is seen as a way to purify your money (Czerny, 2018). In study by (Wahyuni-TD, Fernando, Hasnita, \& Hasnita, 2018) It follows that an Islamic accountant order in accordance with Islamic principles is a catalyst of ethical conduct. In the current market climate of turbulence and the threat of rivals, it is extremely necessary. Islamic ethics can be used as a guide by the Muslim accountant to ensure excellent audit work to comply with Sharia requirements and to provide the socially requested information necessary, such as doing (goodness), (righteousness), (equal and justice), confidence, benevolence, and others. The understanding and application of Islamic ethics aims to provide a more responsible accounting method. Islam is a religion that can set high ethical standards and can offer intense incentives for ethical conduct in all areas of human life, including accounting, which is the absolute essence of ethics that determines religion. For accountants to perform their duty professionally as well as ethically, the task of Islamic ethics is very important (Wahyuni-TD et al., 2018).

The study by (Yarahmadi \& Hoyaryahoocom, 2015) He concluded that accountants should not only be technically trained, but they should also have a high standard of integrity and rectitude in their work. Thus, the professional future of accounting is based on professional accountants' ethical leadership. After the fall of Enron in 2001, ethics in accounting emerged. It was one of the biggest scandals of the last century that gave rise to significant changes in corporate governance around the world, significantly affecting accounting and auditing (Yarahmadi \& Hoyaryahoocom, 2015). Many researchers agree that human society's development depends not only on material or technological advances, but is heavily dependent on ethical changes. We saw what happened when Enron was immoral. (Yarahmadi \& Hoyaryahoocom, 2015). In study by Ahmad et al. (2019) The results show that accounting educators have a similar agreement that the concepts of Islamic ethics are appropriate and necessary to be included in the accounting curriculum in order to produce potential ethical accountants. In addition, respondents urge accounting educators to incorporate Islamic ethics into their method of teaching and learning.

Section one of this paper includes a literature of previous studies in Islamic accounting ethics, while section two of the Islamic accounting ethics research system and business, such as the Accounting and Auditing Body for Islamic Financial Institutions (AAOIFI), the Islamic Financial Services Board (IFSB), and the International Islamic Financial Market (IIFM) and the International Islamic Financial Market (IIFM). Section three Discursion and results compares the activities of Islamic ethics. Finally, concludes and recommendations. 


\section{Research Methods}

This study used a qualitative method in nature based on a conceptual research approached. Conceptual research is regarded as a research methodology in which a research is carried out by studying and interpreting an available data on a particular topic (Kothari, 2002). Conceptual analysis is not really involved in any realistic studies being studied. It has to do with concepts and ideas which are abstract. Conceptual analysis has long been used by philosophers to formulate new ideas or to view current theories in a different light. In order to compare and contrast the findings of these publications in a holistic way, data is obtained from different research journals and idea papers from different journals. A conceptual research approach provides researchers with the best idea of how to conduct the research and analyze the data gained from previous research articles (Blumberg, Cooper, \& Schindler, 2011). The objectives set out in the previous sections of this study concept is directly related to the research methods described in this section. In this study, the methodology is simplified and summarized to serve broad framework of the methods which will be used.

\section{Results and Discussion}

On the Islamic side, in 1998, the only relevant attempt to date has been made by the Accounting and Auditing Organizations of Islamic Financial Institutions (AAOIFI) to develop a Code of Ethics for Accountants to use more reliable technology to make it more user-friendly and competitive, because technology has been responsible for producing valuable knowledge and tools at our fingertips. (Wijerathna, Dissanayake, Navaratne, \& Gunawardena, 2020). The AAOIFI is an agency set up for the purpose, inter alia, of setting, promulgating and updating the accounting standards to be agreed upon by the Member Entities. Independent accountants, internal auditors and external auditors of Islamic financial institutions are subject to the rules of ethical conduct set out in this section of the Code. The AAOIFI Code of Ethics for Accountants sets out an ethical framework, based on Islamic Sharia laws and values, for accountants. The underlying principle of this code is that, on the basis of religious belief and as a means of obedience to the orders of Allah and to refrain from anything He prohibits, Muslim accountants will be obliged to comply with this code. The Code also aims to further improve accountants' ethical knowledge by calling to their attention the ethical issues inherent in professional practice. The accountant needs to be informed about religion-based ethics so that they can see the duty as an obligation to be sincerely performed.

There are three sections in the context of the AAOIFI Code of Ethics: the Sharia Basis for Accounting Ethics, the Accountants' Ethics and the Accountants' Ethics Rules. Seven fundamental pillars are defined in the Sharia Principles of Accounting Ethics, namely, integrity, faith, piety, justice, fear of Allah and duty to Allah. AAOIFI has defined six fundamental ethical standards out of all these seven pillars: trustworthiness, fairness, objectivity, professional competence and honesty, faith-based action, and ethical conduct and professional requirements. Finally, they have developed guiding rules for accountants in their professional practices in all six ethical principles. A detailed analysis of the AAOIFI Code of Ethics will reveal that it is not a solution to the ethical challenges faced by accountants to have a code. For Muslim

In the middle of scandals and accountants' unethical behavior, what can be done to reduce this issue? The answer is Islam, and certain ethical ideas have assumed a broader and more holistic meaning for the accountant. As far as accountability is concerned, the 
accountants in Islam are not strictly accountable to human bosses, managers or clients, and shareholders. They are considered to be servant of God at all times, at the same time they are accountable to God, the creator of himself and the tools which are used and managed by them. Forgetting or neglecting this basic element of this duty is tantamount to betraying divine faith with all its ramifications in this universe (Bhatti, Aslam, Hassan, \& Sulaiman, 2016). An accountant in the Islamic point of view is not only expected to keep positive relationship with their supervisors, customers, and employers, but they are expected to preserve, develop, and reinforce their relationship with God by satisfying their Islamic faith. Islam is a faith that its adherents believed originated from the creator of the universe, a faith that is considered a way of life. Islam has a fundamental ethical concept which, if it is applied in accounting, it might has a function as a remedy to the ethical problem currently facing the profession and will result in Quality of service can facilitate the increase of customer satisfaction (Wattimena \& Sin, 2020). All facets of life are governed in Islam by ethics. Islam has its own personal concept of ethics, taken either from the Sunnah or the Holy Quran. Islam provides the philosophical basis for a variety of human characteristics that foster economic development (Salahudin et al., 2016). Through Sharia's financial structures, more accountability, more visibility and openness are needed to ensure procedural fairness. According to Rahim and Rahman (2003). The study seeks to emphasize the role of ethics in accounting education and to review research developments in this area. This study suggests that, rather than concentrating solely on the moral essence of ethics and the professional code of conduct, the emphasis should be focused on religious ethical growth and principles in the application of accounting ethics. The research points out that Islamic philosophy and ethical point of view may provide some insight into the way a much more self-aware yet ethical auditor can be created.

The major scandals have led the public to question the accountant's facts, why so many businesses truthfully start their business, while others turn them into criminals. The causes of unethical accounting practices are nuanced and interlinked, even after the emergence of several scandals. One could try to rob the business, while others, through incompetence or noble motives, have been increasingly involved in illegal activities.

Greed; there is a very simple truth at the core of a complicated problem. Some people love to get a lot of cash and break the law to get it. Accounting includes the freedom to "cook the books" and get a little or a lot for yourself, even if it is at the person or global level, without actually pointing the gun or breaking into the property of others. Due the mistrust in a study by (Lestari, Maharani, \& Fauzan, 2020) suggest that investors should not only rely on business earnings, but also use other factors in making their decisions, such as potential economic conditions, management efficiency, and government regulations.

Opportunity; Accounting often includes dealing with really large sums of money, although it can easily be concealed, used off or diverted with few risk of being noticed. When faced with this magnitude of pressure, many individuals succumb, especially if those who feel like they are in a position of financial need.

Stress to control the figures; accountants are always under great pressure, particularly when things are not going well with the company. This adds to the urge of the accountant to blur the figures just to have an interesting study. It is a big issue for the accountants, if they are staff or an outside company people hired.

Omission; if they cast a cloud over the company, the accountant often feels pressure to literally leave items out of the financial reports. That is the flip side of purposely distorting numbers, and psychologically it may feel better. 
Confidentiality issues; accountants typically spend a lot of their time dealing with confidential data, such as doctors and lawyers. Using the data illegally or failing to protect sensitive information sufficiently are often ethical concerns for the accountant.

An especially challenging ethical issue to be considered may be conflicts of interest. For example, if senior accountants receive bonuses based on stock prices, they are intentionally or unconsciously motivated to make important decisions that benefit rising stock prices, even if they are not profitable in the long run for the company or its investors.

Ethics education also progressively becomes a part of accounting education. Worrying about level of unethical behavior in practitioners act as an opportunity to integrate ethical training into accounting courses ( Adriaan Taylor, 2013). Recently, ethical education has started to be seen as a required part of the social conditioning of accounting students in the discipline (Clikeman and Henning, 2000). Several studies (Mazraeh and Karimzadeh 2017 ,Jackling et al. 2007, Shafer 2015) have been carried out to determine whether accountants are ethical or whether they consider their profession to be ethical. Accountants were found to have less ethical expertise than expected based on some research findings, but were unable to see an accounting as an ethics code. As result of these problem the research suggest the used of Islamic ethics in accounting curriculums, in to other to improve the ethical level of accountant, because ethics is fundamental in the work of accountant.

\section{Conclusion}

The acknowledgement that a code ethics is essential, but may not have been suitable, had already led many others to reach the conclusion that ethics should be continuously incorporated in the education sector, both at the tertiary level and in vocational education. However, there are many ways which have been formed and can be accompanied throughout the learning of accounting ethics. For example, at least three components for both the introduction of ethics into the accounting profession have been recognized: the allocation of twice the average Introduction Semester to a Business Course on Core corporate ethics; the inclusion of ethics in courses in accounting; and the creation of a master class in management positions case of complex business, social responsibility. Recommendation

\section{Recommendation}

This study suggests the incorporation of Islamic accounting ethics mostly as technique for teaching accounting ethics. The course also should attempt to make students quite familiar with the current challenges faced by professional accountants. The code of conduct of the AAOIFI may be used as a material to define, and from an Islamic viewpoint, students are introduced to the quality of moral knowledge and comprehension. The same practicality of the AAOIFI code would also be confined to following ethical standards such as truthfulness and the like. Ethics is no exception from the Islamic point of view and should be studied as a topic in which students may respond to the major ethical problems they have faced in accounting education and also to the likely ethical decisions they may face when joining the accounting profession. Ethical schooling does not really require a non-critical implementation of professional code of behavior. Exposing students to a constructive threads and discussions about the code of professional ethics, be a diligent and should not consider the ethical codes as merely clear procedures. These enhancements must be decided to deal with professional accountants' ethical issues. 


\section{References}

Adriaan Taylor. (2013). Ethics training for accountants: does it add up? Meditari Accountancy Research, 21(2), 161-177. https://doi.org/http://dx.doi.org/10.1108/MRR-09-2015-0216

Ahmad, N. L. bt, Yusof, R. bt, Mustaffa, W. S. bt W., Wahid, H. bt A., \& Halim, H. bt A. (2019). Developing Ethical Accounting Students through Incorporating Islamic Ethics into Accounting Curriculum: The Educator's Perspectives. International Journal of Academic Research in Business and Social Sciences, 9(1), 248-270. https://doi.org/10.6007/ijarbss/v9-i1/5395

Arif Billah, A. A. A. A., \& Islam, M. A. (2015). Accounting in Islamic Perspective: A Timely Opportunity, a Timely Challenge. IIUC Studies, 9(2), 187-214. https://doi.org/10.3329/iiucs.v9i0.24020

Basri, H., Siti Nabiha, A. K., \& Majid, M. S. A. (2016). Accounting and accountability in religious organizations: An islamic contemporary scholars' perspective. Gadjah Mada International Journal of Business, 18(2), 207-230. https://doi.org/10.22146/gamaijb.12574

Beattie, V. (2000). The future of corporate reporting: a review article. Irish Accounting Review, 7(1), 1-36.

Bhatti, O. K., Aslam, U. S., Hassan, A., \& Sulaiman, M. (2016). Employee motivation an Islamic perspective. Humanomics, 32(1), 33-47. https://doi.org/10.1108/H-10-20150066

Blumberg, B., Cooper, D. R., \& Schindler, P. S. (2011). Business research methods. London: McGraw-Hill Higher Education.

Clikeman, P. M., \& Henning, S. L. (2000). The Socialization of Undergraduate Accounting Students. Issues in Accounting Education, 15(1), 1-17. https://doi.org/10.2308/iace.2000.15.1.1

Costa, M., Torrecchia, P., \& Sangster, A. (2013). Accounting Education for Accounting Educators Evidence from Italy - The Case of SISSIS/TFA (2002-2013)*. Procedia Social and Behavioral Sciences, 106, 295-307. https://doi.org/10.1016/j.sbspro.2013.12.035

Czerny, M. (2018). The influence of religious principles on the formation of the accounting system. Annales. Etyka w Życiu Gospodarczym, 21(8), 31-45. https://doi.org/10.18778/1899-2226.21.8.03

Enofe, A. O., Nakpodia, J. O., \& Moruku, J. A. (2014). Ethics and Role of Accountants. European Journal of Business and ManagementOnline), 6(27), 2222-2839.

Góralska, J. (2016). Ethics in Accounting Outsourcing. Zeszyty Naukowe Uniwersytetu Szczecińskiego Finanse Rynki Finansowe Ubezpieczenia, 80, 107-113. https://doi.org/10.18276/frfu.2016.2.80/2-11

Graham, C. M., Kelly, P., Massey, D. W., \& Van Hise, J. (2013). One size does not fit alldifferent strategies for teaching accounting ethics. Research on Professional Responsibility and Ethics in Accounting, 17, 139-157. https://doi.org/10.1108/S1574-0765(2013)000017008

Hassan, M. K., Aliyu, S., Huda, M., \& Rashid, M. (2019). A survey on Islamic Finance and accounting standards. Borsa Istanbul Review, 19, S1-S13. https://doi.org/10.1016/j.bir.2019.07.006

Indrawaty, \& Wardayati, S. M. (2016). Implementing Islamic Corporate Governance (ICG) and Islamic Social Reporting (ISR) in Islamic Financial Institution (IFI). 
Procedia - Social and Behavioral Sciences, 219, 338-343. https://doi.org/10.1016/j.sbspro.2016.04.042

Jackling, B., Cooper, B. J., Leung, P., \& Dellaportas, S. (2007). Professional accounting bodies' perceptions of ethical issues, causes of ethical failure and ethics education. Managerial Auditing Journal, 22(9), 928-944. https://doi.org/10.1108/02686900710829426

Jaijairam, P. (2017). Ethics in Accounting. (November).

Kamla, R. (2015). Critical Muslim intellectuals' thought: Possible contributions to the development of emancipatory accounting thought. Critical Perspectives on Accounting, 31, 64-74. https://doi.org/10.1016/j.cpa.2015.01.014

Kamla, R., Gallhofer, S., \& Haslam, J. (2006). Islam, nature and accounting: Islamic principles and the notion of accounting for the environment. Accounting Forum, 30(3), 245-265. https://doi.org/10.1016/j.accfor.2006.05.003

Khafit, A., Sulastri, S., \& Fauzan, S. (2020). Technology Acceptance Model (TAM): Measurement Of E- Learning Use by Accounting Students at Malang State University. Asia Pacific Journal of Management and Education, 3(3), 64-72. https://doi.org/10.32535/apjme.v3i3.969

Kothari, C. R. (2002). Research Methodology: Method \&amp; Techniques.

Kutluk, F. A., Donmez, A., Utku, B. D., \& Erdogan, M. (2012). Expectation of Accounting Professionals From Accounting Education: An Antalya Research. Procedia - Social and Behavioral Sciences, 62, 418-423. https://doi.org/10.1016/j.sbspro.2012.09.068

Lestari, N., Maharani, S. N., \& Fauzan, M. S. (2020). Analysis of Differences in Measurement of Fair Value and Historical Value of Biological Assets on Income Smoothing (Study on Agricultural Companies in Southeast Asia And Australia). International Journal of Accounting \& Finance in Asia Pasific, 3(3), 76-88. https://doi.org/10.32535/ijafap.v3i3.955

Mahdavikhou, M., \& Khotanlou, M. (2012). New Approach to Teaching of Ethics in Accounting "Introducing Islamic Ethics into Accounting Education." Procedia Social and Behavioral Sciences, 46, 1318-1322. https://doi.org/10.1016/j.sbspro.2012.05.294

Martinelli, I., et al. (2019). Community Economic Development Prospect Based on Wakaf Funds. Budapest International Research and Critics Institute-Journal (BIRCIJournal), P. 409-423.

Mazraeh, Y. A., \& Karimzadeh, H. (2017). The Role of Ethics on Accounting. SSRN Electronic Journal. https://doi.org/10.2139/ssrn.2901664

Melé, D. (2005). Ethical education in accounting: Integrating rules, values and virtues. Journal of Business Ethics, 57(1), 97-109. https://doi.org/10.1007/s10551-004-3829$\mathrm{y}$

Melé, D., Rosanas, J. M., \& Fontrodona, J. (2017). Ethics in Finance and Accounting: Editorial Introduction. Journal of Business Ethics, 140(4), 609-613. https://doi.org/10.1007/s10551-016-3328-y

P, H. A., \& Andriyani, D. E. (2020). Public Relations Management in Building the Image of Schools in Senior High School. Journal of The Community Development in Asia, 3(3), 1-6. https://doi.org/10.32535/jcda.v3i3.885

Rahim, A., \& Rahman, A. (2003a). Ethics In Accounting Education : Contribution Of The Islamic Principle Of Maêlaîah. 1(1), 1-18.

Rahim, A., \& Rahman, A. (2003b). Ethics in Accounting Education: Contribution of the Islamic Principle of Maslahah. IIUM Journal of Economics and Management, 11(1), $21-50$. 
Rahmani, N. A. B., Maksum, A., Fachrudin, K. A., \& Silalahi, A. S. (2020). Analysis of the Effect of Profitability on General Corporate Information and Forward-looking Information and its impact on the Company's Share Prices listed on the Indonesia Stock Exchange. International Journal of Accounting \& Finance in Asia Pasific, 3(3), 32-38. https://doi.org/10.32535/ijafap.v3i3.950

Rezaei, M. (n.d.). Islamic Accounting laws or Islamic laws in Accounting. 1-8.

Salahudin, S. N. bin, Baharuddin, S. S. binti, Abdullah, M. S., \& Osman, A. (2016). The Effect of Islamic Work Ethics on Organizational Commitment. Procedia Economics and Finance, 35(August), 582-590. https://doi.org/10.1016/s2212-5671(16)00071-x

Shafer, W. E. (2015). Ethical climate, social responsibility, and earnings management. Journal of Business Ethics, 126(1), 43-60. https://doi.org/10.1007/s10551-013-19893

Trokic, A. (2015). Islamic Accounting; History, Development and Prospects. Islamic Accounting; History, Development and Prospects, (3), 1-6. https://doi.org/10.13135/2421-2172/1043

Wahyuni-TD, I. S., Fernando, Y., Hasnita, E., \& Hasnita, E. (2018). Role of Islamic Ethics Towards Ethical Accounting Practice. Journal of Governance and Integrity, 2(1), 2327. https://doi.org/10.15282/jgi.2.1.2018.5535

Wattimena, R. E., \& Sin, L. G. (2020). Building Trust and Quality of Customer Service Through Customer Satisfaction (Study of Gojek's Customers in Malang City). Journal of The Community Development in Asia, 3(3), 79-87. https://doi.org/10.32535/jcda.v3i3.892

Wijerathna, R. M. S., Dissanayake, U., Navaratne, S., \& Gunawardena, D. (2020). Evaluation of a Mobile SMS based Twitter Information Service for Rural communities: A Case study of Ipologama Vidatha Resource Center, Sri Lanka. Journal of The Community Development in Asia, 3(3), 19-28. https://doi.org/10.32535/jcda.v3i3.733

Yarahmadi, H., \& Hoyaryahoocom, E. (2015). Ethics in Accounting. 5(1), 356-360. https://doi.org/10.5296/ijafr.v5i1.7829 